\title{
Effect of sperm DNA fragmentation on embryo development: clinical and biological aspects
}

\author{
Cristian Alvarez Sedó ${ }^{1}$, Melina Bilinski ${ }^{1}$, Daniela Lorenzi ${ }^{1}$, Heydy Uriondo ${ }^{1}$, Felicitas Noblía ${ }^{1}$, Valeria Longobucco ${ }^{1}$, \\ Estefanía Ventimiglia Lagar $^{1}$, Florencia Nodar ${ }^{1}$ \\ ${ }^{1}$ Centro de Estudios en Genética y Reproducción (CEGYR), Buenos Aires, Argentina
}

\begin{abstract}
Objective: The aim of this study was to investigate the effect of sperm DNA fragmentation on fertilization rate, embryo development (blastulation rate), and pregnancy outcomes for ICSI cycles performed in a cohort of couples using donor eggs and to assess the remaining embryos that were not transferred or frozen for apoptotic markers.

Methods: Eighty-two women (egg recipients) were included in the study (2016). The recipients' mean age was $41.8 \pm 5.1 \mathrm{y} / \mathrm{o}(36-49)$, while the egg donors' mean age was $30.8 \pm 2.1 \mathrm{y} / \mathrm{o}(27-33)$. Even though donor egg cycles with frozen sperm samples are performed regularly in our center, 35 cycles were done using fresh sperm samples. The mean age of the males involved in the procedure was $40.1 \pm 5.2$ y/o. Fertilization, blastulation, and pregnancy rates were assessed. The patients were divided into two groups, TUNEL $<15 \%$ and $\geq 15 \%$. In arrested embryos, ICC was performed to detect cleaved caspase-3, survivin, TUNEL, and DNA. The Student's $t$-test was used in betweengroup comparisons. The Mann-Whitney U-test was used to assess homogeneity. Pearson's correlation coefficient was also calculated. $p<0.05$ was considered statistically significant.
\end{abstract}

Results: This study showed that there is a negative correlation $(R=-0.5)$ between DNA fragmentation and blastulation rate. High levels of DNA fragmentation were associated with low blastulation and pregnancy rates (per transfer); however, fertilization rate was not affected. Samples with higher levels of DNA fragmentation were associated with higher levels of DNA fragmentation in blastomeres without activating the apoptotic pathway $(9.1 \%$ vs. $15.9 \%)(p<0.05)$. Blastomeres from samples with high DNA fragmentation activated the apoptotic pathway in higher levels than samples with TUNEL $<15 \%$ $(16.4 \%$ vs. $21.9 \%)(p<0.05)$.

Conclusion: Sperm DNA fragmentation was negatively correlated with blastulation and pregnancy rates even in good quality oocytes. High levels of DNA damage promote embryo arrest and induce the activation of the apoptotic pathway.

Keywords: blastocyst, DNA fragmentation, blastulation rate

\section{INTRODUCTION}

Male factor accounts for $30-40 \%$ of all cases of human infertility. In the past, medical decisions on treating infertile couples were based mostly on the results of conventional semen analysis, assessing sperm concentration, motility, and morphology in one or more semen samples.

In the early days of ART, severe male factor infertility yielded frustrating results, in the form of poor fertilization and pregnancy rates. With the preliminary reports on ICSI (intracytoplasmic sperm injection) in the early 1990s, clinicians and embryologists believed a solution had been found to all cases of male factor infertility. However, unsuccessful treatments despite the use of ICSI have indicated that other factors may be involved, including sperm DNA fragmentation or sperm morphologic damage undetected by the standard magnification used in conventional ICSI. More recently, several number of techniques designed to improve sperm selection for conventional ICSI have demonstrated to increase fertilization rates, enhance embryo quality after successful fertilization, and optimize pregnancy rates.

Several studies have demonstrated the importance of the stability of sperm nuclei and its correlation with successful reproduction in animals and humans, and the association of sperm nucleus damage with low fertilization rates, poor embryo implantation, and increased miscarriage rates (Aitken et al., 1998; Morris et al., 2002; Bungum et al., 2004; Carrell et al., 2003; Seli et al., 2004; Virro et al., 2004; Lewis \& Aitken, 2005; Aitken et al., 2009; Meseguer et al., 2008; Zini \& Sigman, 2009; De Iuliis et al., 2009; Barratt et al., 2010; Sakkas \& Alvarez, 2010).

DNA damage may occur in the form of single or double strand breaks, and both types can be analyzed and/ or quantified through different methods, including SCD (Sperm chromatin dispersion), SCSA (Sperm Chromatin Structure Assay) and TUNEL (terminal deoxynucleotidyl transferase dUTP nick end labeling) (Evenson et al., 1980; Gorczyca et al., 1993; Fernández et al., 2005; Chohan et al. , 2006). DNA damage may have a negative impact in IVFICSI results (Evenson et al., 2002; Cordelli et al., 2005; Sergerie et al., 2005; Greco et al., 2005; Boe-Hansen et al., 2006; Makhlouf \& Niederberger, 2006; Avendaño et al., 2009a; Avendaño et al., 2009b; Góngora-Rodríguez \& Fontanilla-Ramírez, 2010; Borini et al., 2006; Ni et al., 2014).

In the first days of embryo culture, morphological criteria alone are generally poor predictors of embryo development and ability to achieve pregnancy (Guerif et al., 2010; Nel-Themaat \& Nagy, 2011). However, embryos are still categorized and chosen for transfer based on morphological and developmental scores (Alpha Scientists in Reproductive Medicine and ESHRE Special Interest Group of Embryology, 2011).

Higher levels of DNA fragmentation (SDF >30\%) in sperm cells have been associated with lower blastocyst formation rates (Virro et al., 2004). Nasr-Esfahani et al. (2005) reported that embryos derived from spermatozoa with high levels of DNA damage are less likely to reach later developmental or blastocyst stages. However, in these studies the blastulation rates between the groups with SDF $>30 \%$ and SDF $<30 \%$ in IVF cycles were not different. The most likely explanation for this is "natural" selection during IVF. In that sense, it seems that ICSI results and embryo development (ICSI) are significantly affected by sperm quality.

Finally, regarding apoptosis, anomalies in cell death control have been implicated as a cause or contributing 
factor in a range of diseases, including cancer, autoimmunity, and degenerative disorders. Cell death control involves several proteins that promote or inhibit apoptosis and an evolutionarily conserved multistep cascade. A number of proteins, such as $\mathrm{Bcl}-2$, Fas and Bax, affect processes upstream of the cascade. Survivin, an apoptosis inhibitor, may prolong cell survival by targeting terminal effector caspase-3. Located at the end of the cascade, caspase-3 acts as both an initiator and executor of the apoptotic process. Therefore, survivin and caspase- 3 have received significant attention in the discussions on apoptosis ( $\mathrm{Li}$ et al., 2004).

This study looked into the effect of sperm DNA fragmentation on fertilization rates, embryo development (blastulation rate), and pregnancy outcomes of couples using donor eggs offered ICSI cycles. The remaining embryos that were not transferred or frozen were also assessed for apoptotic markers.

\section{MATERIALS AND METHODS}

\section{Population}

This study included 82 egg recipients submitted to ART procedures (2016). The recipient's mean age was $41.8 \pm 5.1$ $y / 0$ (36-49) and the mean age of the oocyte donors was $30.8 \pm 2.1$ y/o (27-33). Even though donor egg cycles with frozen sperm samples are performed regularly in our center, 35 cycles were done using fresh sperm samples. The mean age of the males involved in the procedure was $40.1 \pm 5.2$ y/o.

Egg donors had to comply with the following requirements of the egg donation program: antral follicle count $>16$, negative serology, psychological and genetic counseling, and normal karyotype. A clinical geneticist tested the patients for relevant family history.

\section{Egg donor controlled ovarian stimulation}

The donors were placed on a flexible GnRH antagonist protocol for ovarian stimulation, with daily doses of 225-300 IU of a gonadotropin (Menopur ${ }^{\circledR}$ ) (Ferring) daily. When the leading follicle reached a diameter of $14 \mathrm{~mm}, \mathrm{GnRH}$ antagonist Orgalutran (MSD) was administered daily until the day of Lupron ${ }^{\circledR}$ injection. Once the leading follicle reached $17-18 \mathrm{~mm}$ in diameter and estradiol levels were $>+500 \mathrm{pg} / \mathrm{ml}$, leuprolide acetate (Lupron ${ }^{\circledR}, 2 \mathrm{mg}$ ) was administered 36 hours prior to oocyte retrieval. Then the IVF procedure (ICSI) was performed.

\section{Endometrial preparation for ET}

Seventy-five embryo transfers (blastocyst) were performed; patients received oral estradiol Valerate (Ronfase $^{\circledR}$ ) $4 \mathrm{mg}$ daily from day 2 of the menstrual cycle. On day 10, an ultrasound examination was performed. After ultrasound confirmation of endometrial thickness $>6 \mathrm{~mm}$ and absence of ovarian activity, progesterone (Utrogestan ${ }^{\circledR}$ ) $600 \mathrm{mg}$ daily was added for 5 days before ET and up to 14 weeks afterwards when pregnancy was confirmed.

The dose of Ronfase was increased to $6 \mathrm{mg}$ daily if endometrial thickness was less than $6 \mathrm{~mm}$. Ultrasound examination was repeated within 7 days and cycles were cancelled if the endometrium failed to reach the minimum thickness.

\section{Source of embryos}

All remaining human embryos were donated for research with the consent of the couples submitted to ART procedures at CEGyR (Buenos Aires, Argentina). The Internal Review Board and Ethics Committee of CEGyR approved the procedures involving human embryos. None of the presumed embryos donated for this project were transferred to recipients after ICSI. If they had not been donated to this research, these embryos would have been discarded. All embryos were fixed immediately 5 days after oocyte fertilization was confirmed.

\section{Chemicals and antibodies}

All chemicals were obtained from Sigma Chemical Co. (St. Louis, MO, USA), unless stated otherwise. Cleaved caspase-3 (CC3) and Survivin (Surv) were detected using anti-full-length human CC3 (rabbit monoclonal, dil: 1:100, Cell Signaling, USA), and Surv (mouse monoclonal, dil: $1: 100$, Novus Biologicals, USA). Alexa Fluor secondary antibodies were obtained from Molecular Probes (Invitrogen, US). TUNEL (Roche, USA) assays were also performed to detect DNA fragmentation. Hoechst 33258 (Sigma) was used for DNA staining.

\section{Embryo processing}

One hundred and eighty-seven embryos from 82 patients were collected after ICSI and studied. All embryos were individually processed. The zona pellucida was slightly dissolved by incubation in acidic Tyrode's solution (Irvine Scientific, US), and then the embryos were fixed and processed by immunocytochemistry (ICC) (see below).

\section{Detection of cell damage and apoptosis in} embryos by immunohistochemistry

The human embryos were fixed for $45 \mathrm{~min}$ in $2 \%$ formaldehyde and washed with PBS $+0.1 \%$ Triton X-100 for an additional 45 min (method modified and based on Messinger and Albertini, 1991). After fixation and washing, the samples were blocked for at least $1 \mathrm{~h}$ in PBS $+0.3 \%$ bovine serum albumin (BSA) $+1 \%$ fetal calf serum prior to incubation in humidified chambers with primary and secondary antibodies overnight at $4^{\circ} \mathrm{C}$ and for 2 hours at $37^{\circ} \mathrm{C}$, respectively. The embryos were washed several times with PBS-BSA. After washing, they were incubated in TUNEL solution for 1 hour at $37^{\circ} \mathrm{C}$. Finally, the embryos were incubated with Hoechst 33258 for DNA detection. Some images were obtained using an Olympus spectral confocal microscope, with laser lines at 488-, 568- and $633-\mathrm{nm}$ wavelengths and then processed using Adobe Photoshop C5; additional images were captured with an Olympus BX40 Fluorescence Microscope. Negative controls were run in the absence of primary antibodies. This assay allowed us to determine the cytoplasmic activation of CC3 in the blastomeres of each of the embryos (apoptosis); Surv activation meant that the cell performed a strategy to stop the cell death; TUNEL (positive) meant that DNA fragmentation (damage) had occurred, but nuclear condensation and TUNEL were the final evidence of cell death by apoptosis (Figures 1 and 2).

\section{Sperm analysis and DNA fragmentation}

Semen analysis was performed accordingly to the procedure established by the WHO (2010). After motile sperm isolation, the samples were fixed in $2 \%$ formaldehyde in phosphate-buffered saline solution (PBS; $\mathrm{pH}$ 7.4) for at least 1 hour. Each sample was placed into one well of a multiwell (4-mm diameter) Teflon-printed slide (Electron Microscopy Sciences) and allowed to settle. After 2-3 hours, each well was washed with 1 X PBS (three times, 5 minutes each); the cells were then permeabilized with cold methanol. Before incubation with TUNEL solution, each well was washed again with $1 X$ PBS. For each sample, one extra well was incubated with DNAse $(1 \mathrm{U} / \mathrm{mL}$; Sigma) for 30 minutes at $37^{\circ} \mathrm{C}$ as a positive control, and in another well the TUNEL "enzyme' 'solution was omitted 


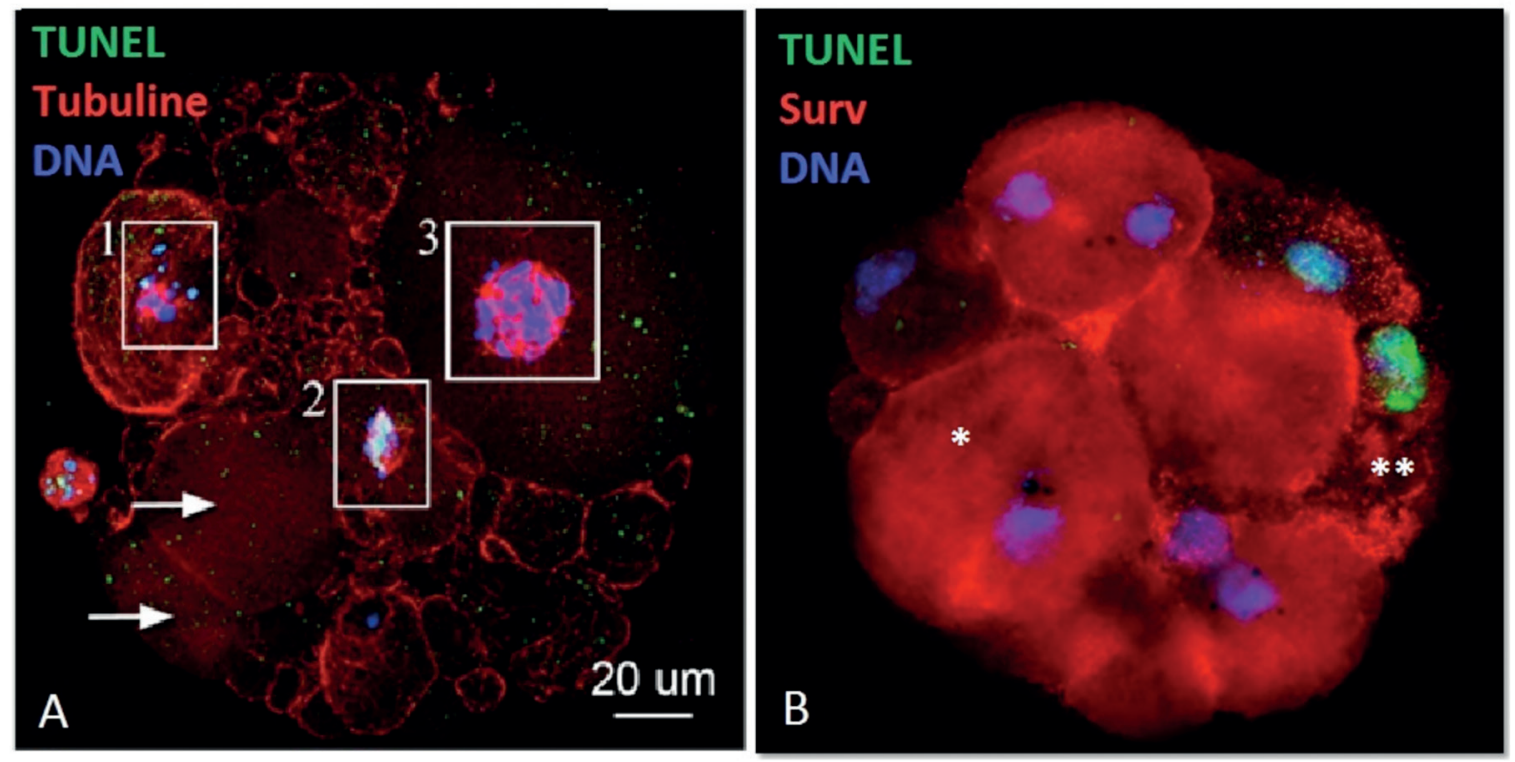

Figure 1. In A, ICC for TUNEL and DNA staining fragmented DNA ( 1 and 2$)$, non-fragmented DNA (3), and some blastomeres without DNA (arrows). In B, Blastomeres without DNA damage and Surv $(+)(*)$ or DNA fragmentation and Surv $(-)(* *)$.
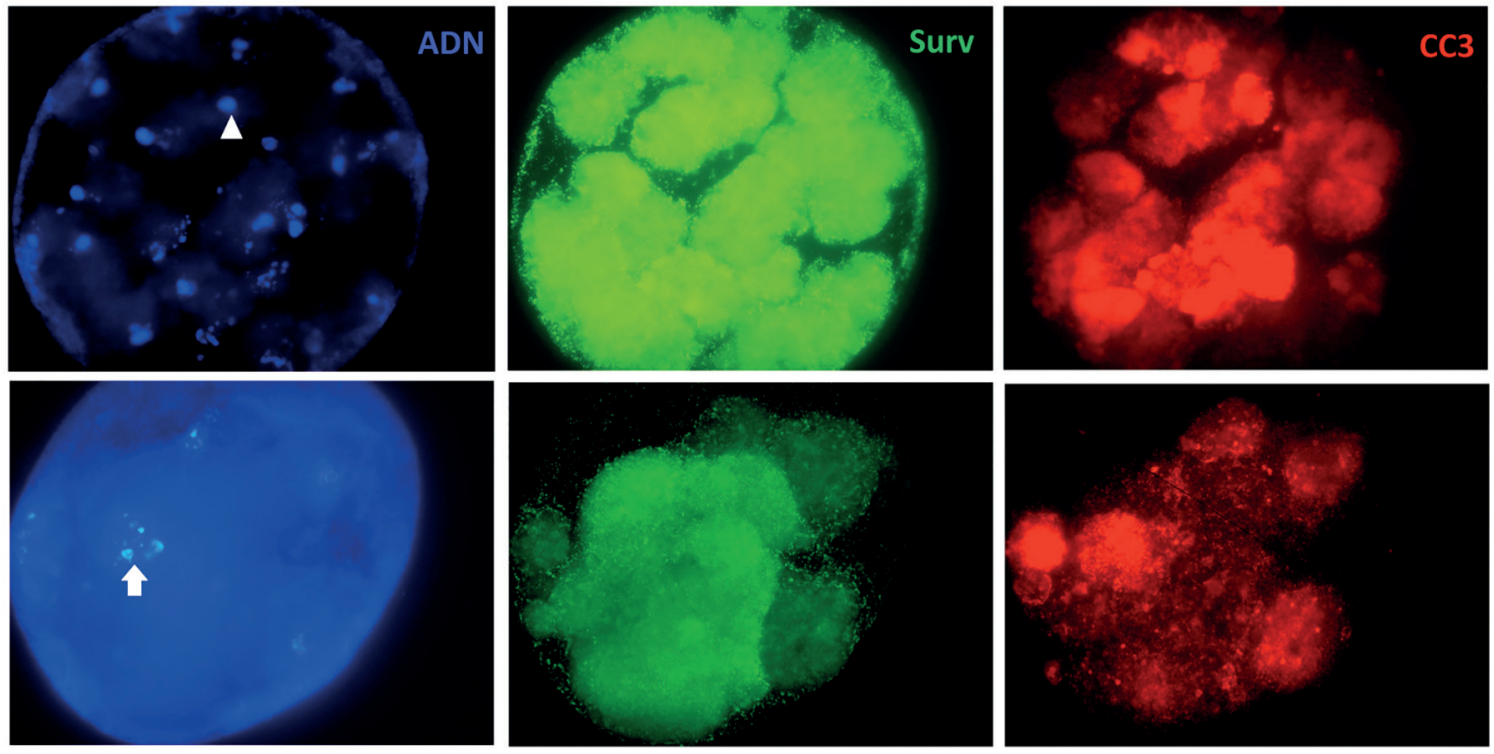

Figure 2. Embryos with condensed DNA (arrowhead) and TUNEL (+) (arrow). Surv and CC3 show different positive staining.

as a negative control. Then all samples were incubated in TUNEL solution (Roche, ) for 1 hour at $37^{\circ} \mathrm{C}$. All samples were finally washed with 1X PBS (three times, 5 minutes each), and mounted in Vectashield $\mathrm{H}-1000$ medium (Vector Laboratories). 500 spermatozoa were counted by fluorescence microscopy. TUNEL staining was evaluated on a fluorescence microscope using a green filter (fluorescein isothiocyanate, $488 \mathrm{~nm}$ ) (Figure 3).

\section{Statistics}

The Student's $t$-test was used for between-group comparisons. The Mann-Whitney $U$-test was used to assess homogeneity. Pearson's correlation coefficient was also calculated. $p<0.05$ was considered statistically significant. Statistical analyses were carried out on software program MedCalc 12.5 (Belgium).

\section{RESULTS}

Table 1 shows sperm analysis data. Clinical outcomes (ICSI results) in terms of fertilization, blastulation, and pregnancy rates are shown in Table 2 . The same data is shown in Table 3 for sperm samples with high $(\geq 15)$ or low $(<15 \%)$ levels of DNA fragmentation. The results revealed the existence of a negative correlation $(R=-0.5)$ between DNA fragmentation and blastulation rates (Fig. 4), and an association between high levels of DNA fragmentation and low blastulation and pregnancy rates (per transfer); however, fertilization rate was not affected.

On the other hand, when the remaining embryos were analyzed, samples with higher levels of DNA fragmentation were observed to induce higher levels of DNA fragmentation in blastomeres without activating the 


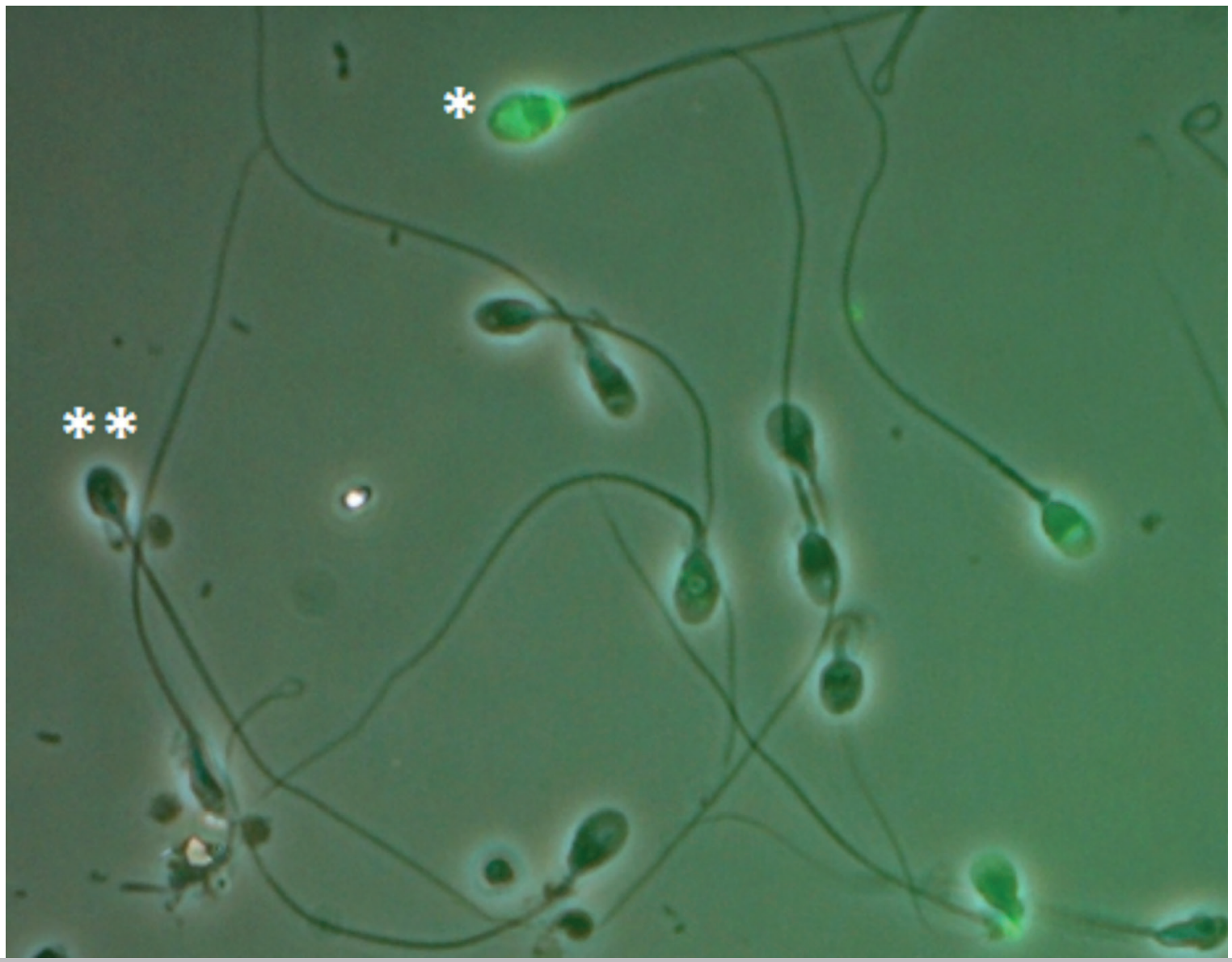

Figure 3. TUNEL assay to assess sperm DNA fragmentation. Positive cells $(*)$, negative cells $(* *)$.

\begin{tabular}{|l|c|}
\hline Table 1. Results of sperm analysis performed according to the WHO guidelines (2010). \\
\hline Sperm parameters (\%) & $\mathbf{N}=\mathbf{8 2}$ \\
\hline Volume $(\mathbf{m L})$ & $2.7 \pm 0.8$ \\
\hline Sperm Concentration (mill/mL) & $68.5 \pm 43.1$ \\
\hline Sperm Morphology using Kruger's strict criteria & $6.5 \pm 3.8$ \\
\hline Sperm Progressive Motility (a+b) & $50.8 \pm 16.9$ \\
\hline PMN & $0.96 \pm 1.64$ \\
\hline DNA fragmentation (TUNEL) & $13.5 \pm 11.1$ \\
\hline
\end{tabular}

\begin{tabular}{|l|c|c|}
\hline Table 2. Clinical outcomes for the studied population. & X \pm SD & Min-Max \\
\hline Clinical outcomes & $41.8 \pm 5.2$ & $36-49$ \\
\hline Female age & $30.8 \pm 2.1$ & $27-33$ \\
\hline Donor age & $40.1 \pm 5.2$ & $33-60$ \\
\hline Male age & $8.7 \pm 2.1$ & $4-14$ \\
\hline No of oocytes assigned (MII) & $75.4 \pm 18.9$ & $20-100$ \\
\hline Fertilization rate (\%) & $51.8 \pm 26.3$ & $0-100$ \\
\hline Blastulation rate (\%) & $50 / 75$ & $67 \%$ \\
\hline Pregnancy rate (\%)/transfer & & \\
\hline
\end{tabular}


Table 3. Clinical outcomes - Comparison between patients with TUNEL $<15 \%$ vs. $\geq 15 \%$.

\begin{tabular}{|l|c|c|c|}
\hline & $\begin{array}{c}\text { DNA fragmentation } \\
\mathbf{1 0 \%}\end{array}$ & $\begin{array}{c}\text { DNA fragmentation } \\
\mathbf{1 1 5} \%\end{array}$ & $\boldsymbol{p}$ \\
\hline $\mathbf{N}$ & 54 & 28 & 0.75 \\
\hline No of oocytes assigned (MII) & $8.9 \pm 2.3$ & $5.9 \pm 4.2$ & 0.40 \\
\hline Strict morphology (\%) & $6.5 \pm 3.1$ & $24.9 \pm 11.5$ & $\mathbf{0 . 0 0 1}$ \\
\hline DNA fragmentation (\%) & $7.6 \pm 3.8$ & $73.8 \pm 18.2$ & 0.62 \\
\hline Fertilization rate (\%) & $76.1 \pm 19.4$ & $37.5 \pm 28$ & $\mathbf{0 . 0 0 3}$ \\
\hline Blastulation rate (\%) & $59.2 \pm 22$ & $12 / 24$ & $\mathbf{0 . 0 6}$ \\
\hline Pregnancy rate (\%)/transfer & $38 / 51$ & $50 \%$ & \\
\hline
\end{tabular}

\section{Correlation between DNA fragmentation and Blastulation rate}

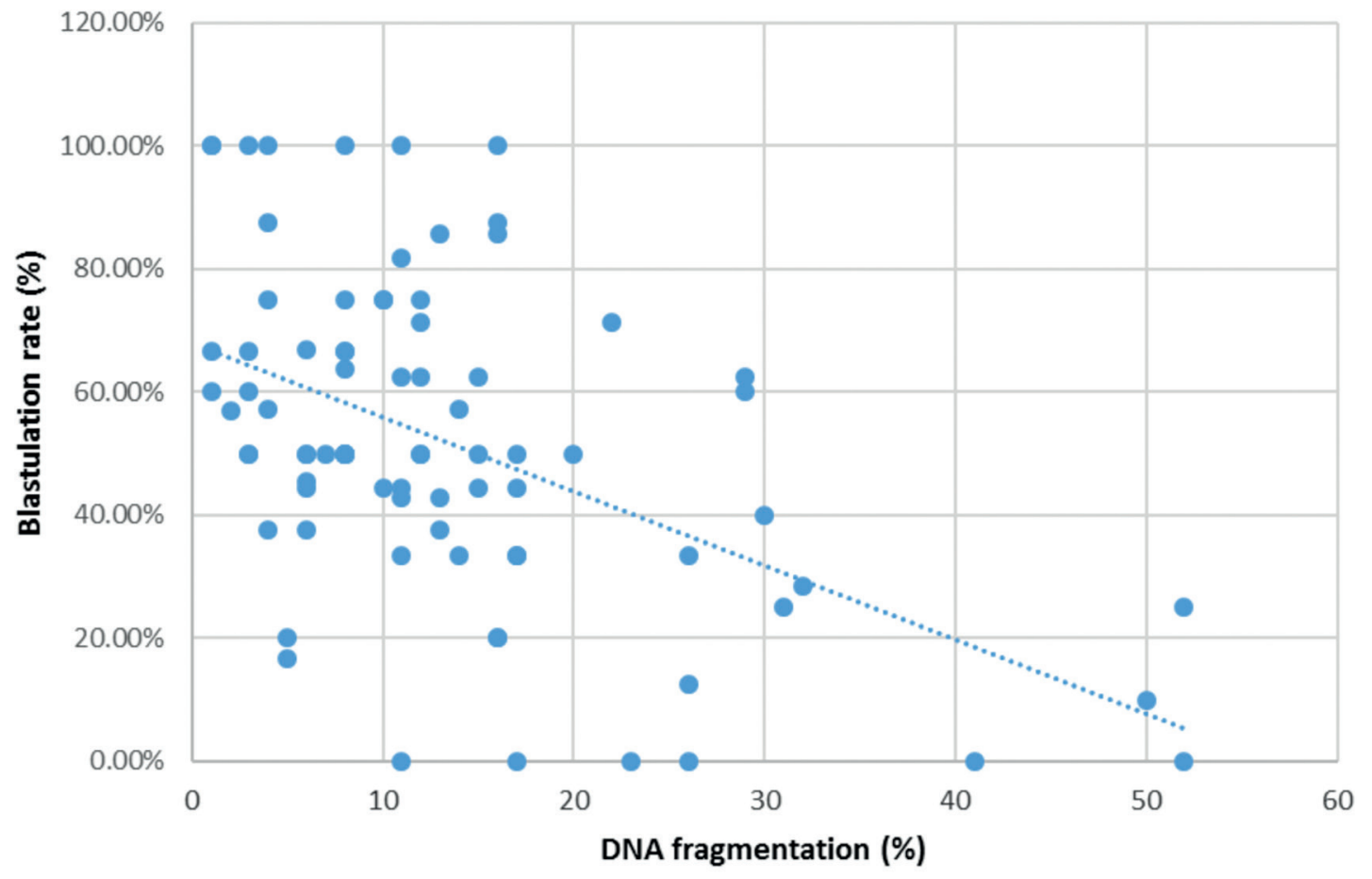

Figure 4. Correlation analysis between DNA fragmentation and Blastulation rate $(R=-0.5)$.

apoptosis pathway ( $9.1 \%$ vs. $15.9 \%)(p<0.05)$. Likewise, blastomeres from samples with high DNA fragmentation activated the apoptotic pathway in higher levels than TUNEL $<15 \%(16.4 \%$ vs. $21.9 \%)(p<0.05)$. The final expression of cell death, TUNEL $(+)$, Surv $(+)$, CC3 (+) and DNA condensation, was increased in embryos coming from sperm samples with high levels of DNA damage $(3.0 \%$ vs. $8.8 \%)(p<0.05)$. Finally, when TUNEL and CC3 were positive and Surv was negative, there were no statistical differences between groups (Table 4 ).

\section{DISCUSSION}

Semen quality is usually expressed in terms of sperm concentration, motility, and morphology (WHO, 2010). Our group previously reported that these parameters, specifically morphology and motility, were closely related to DNA alterations (Uriondo et al., 2011, Alvarez Sedó et al., 2012). Though sperm DNA damage is not considered in regular sperm analysis, the literature suggests that sperm DNA damage produces relevant impact on male fertility. Various theories have been put forward to explain sperm DNA damage (apoptosis, chromatin remodeling, oxidative damage) (Sakkas \& Alvarez, 2010).

During the course of natural selection, effective conception can only occur following the fertilization of an oocyte by sperm with intact DNA. However, assisted reproductive technologies have increased the possibility of anomalous spermatozoa being used to fertilize oocytes (Tavukçuoğlu et al., 2012). Sperm DNA fragmentation is an important parameter of sperm quality that can be 
Table 4. Blastomere analysis - Comparison between patients with TUNEL $<15 \%$ vs. $\geq 15 \%$.

\begin{tabular}{|c|c|c|c|}
\hline & $\begin{array}{l}\text { DNA fragmentation } \\
<15 \%\end{array}$ & $\begin{array}{l}\text { DNA fragmentation } \\
\geq 15 \%\end{array}$ & $\boldsymbol{p}$ \\
\hline No embryos & 112 & 75 & \\
\hline $\mathrm{N}^{\circ}$ of Blastomeres assessed & 860 & 432 & \\
\hline Blastomeres without DNA damage & $458(53.2 \%)$ & $137(31.7)$ & 0.0001 \\
\hline $\begin{array}{l}\text { Blastomeres with DNA damage } \\
\text { CC3 }(-) \text { Surv }(-)\end{array}$ & $78(9.1 \%)$ & $69(15.9 \%)$ & 0.0004 \\
\hline $\begin{array}{l}\text { Blastomeres with DNA damage } \\
\text { CC3 (+) Surv (-) }\end{array}$ & $132(15.3 \%)$ & $76(17.6 \%)$ & 0.29 \\
\hline $\begin{array}{l}\text { Blastomeres without DNA damage } \\
\text { CC3 }(+) \text { Surv }(+)\end{array}$ & $25(2.9 \%)$ & $17(3.9 \%)$ & 0.45 \\
\hline $\begin{array}{l}\text { Blastomeres with DNA damage } \\
\text { CC3 }(+) \text { Surv }(+)\end{array}$ & $141(16.4 \%)$ & $95(21.9 \%)$ & 0.007 \\
\hline $\begin{array}{l}\text { Blastomeres with DNA damage } \\
\text { CC3 (+) Surv (+) Nuclear condensation }\end{array}$ & $26(3.0 \%)$ & $38(8.8 \%)$ & 0.0001 \\
\hline
\end{tabular}

used to assess sperm nuclear integrity, which itself plays an important role in fertilization and embryo development (Bungum et al., 2007). The role of male factor infertility on embryo development has gained attention since the introduction of ICSI as a treatment option for patients with very poor sperm characteristics. Our study demonstrated that blastulation rates were associated with high levels of DNA damage, suggesting a very early onset of paternal effects on embryo development.

In the present study, sperm DNA damage was assessed by TUNEL assay, performed on motile sperm prepared with a swim-up procedure and used for ICSI. Our group previously demonstrated that the predictive ability of the sperm DNA integrity test, performed on raw sample, diminished when spermatozoa were prepared using techniques such as Swim-up or centrifugation density gradient (Rougier et al., 2013, Alvarez Sedó et al., 2013). However, in our population, several samples had high levels of DNA fragmentation even after motile sperm isolation.

This preliminary data found no relationship between sperm DNA damage and fertilization rates in ICSI $(p=0.62)$, but the blastulation rate was clearly diminished when DNA damage was high $(p<0.05)$. On the other hand, patients with low DNA fragmentation $(<15 \%)$ had a clear tendency to attaining higher pregnancy rates $(p=0.06)$. These results may be accounted for by the fact that high DNA fragmentation probably does not impede fertilization, but prevents blastulation and/or successful embryo development (Ahmadi \& Ng, 1999). However, this issue was mostly observed in ICSI patients; when IVF was performed, these differences were not evinced, probably due to "natural" selection of sperm by the oocyte (Borini et al., 2006). The amount of sperm DNA damage was related to embryo development to the blastocyst stage, a time when the embryonic genome is activated, transcriptional activity has begun, and the paternal genome plays a significant role in embryo function toward implantation (Seli et al., 2004).

This is the first report that used an egg donation model to assess the impact of DNA damage over clinical and biological outcomes. Our biological results showed that sperm DNA damage might promote blastomere DNA fragmentation without the activation of the apoptotic machinery, probably due the injection of sperm with slight DNA damage that was able to advance during the embryonic development. However, other mechanisms might be at play in embryo arrest. On the other hand, most of the blastomeres showed a complete apoptotic pattern (TUNEL $(+)$, CC3 $(+)$ and Surv $(+))$, revealing that good quality oocytes respond adequately to the induction of apoptosis. However, this was observed largely in embryos that came from samples with high levels of DNA damage, confirming that sperm damage can cause further arrest in embryonic development.

In conclusion, our data indicated that sperm DNA fragmentation significantly affected embryo blastulation and implantation in ICSI patients who received donated eggs. More specifically, this study showed, for the first time, that sperm DNA fragmentation might compromise the progression of embryo development, resulting in arrested embryos. This study also underlined the better predictive value of DNA fragmentation analysis versus traditional sperm parameter evaluation in the assessment of ART outcomes. For this reason, sperm DNA fragmentation should be considered during the assessment of semen quality.

\section{CONCLUSIONS}

Sperm DNA fragmentation had a negative correlation with blastulation and pregnancy rates even with good quality oocytes. High DNA damage levels promoted embryo arrest and induced the activation of the apoptotic machinery.

\section{CONFLICT OF INTERESTS}

The authors had no conflicts of interest to declare.

\section{Corresponding author:}

Cristian Alvarez Sedó

Centro de Estudios en Genética y Reproducción (CEGYR)

Buenos Aires, Argentina

E-mail address: calvarez@cegyr.com

\section{REFERENCES}

Ahmadi A, Ng SC. Fertilizing ability of DNAdamaged spermatozoa. J Exp Zool. 1999;284:696704. PMID: 10531556 DOI: 10.1002/(SICI)1097010X(19991101)284:6<696: :AID-JEZ11>3.0.CO;2-E 
Aitken RJ, Gordon E, Harkiss D, Twigg JP, Milne P, Jennings $Z$, Irvine DS. Relative impact of oxidative stress on the functional competence and genomic integrity of human spermatozoa. Biol Reprod. 1998;59:1037-46. PMID: 9780307 DOI: 10.1095/biolreprod59.5.1037

Aitken RJ, De Iuliis GN, McLachlan RI. Biological and clinical significance of DNA damage in the male germ line. Int J Androl. 2009;32:46-56. PMID: 19076252 DOI: 10.1111/j.1365-2605.2008.00943.x

Alpha Scientists in Reproductive Medicine and ESHRE Special Interest Group of Embryology. The Istanbul consensus workshop on embryo assessment: proceedings of an expert meeting. Hum Reprod. 2011;26:1270-83. PMID: 21502182 DOI: 10.1093/humrep/der037

Alvarez Sedó C, Gil MV, Serna J, Nodar F, Papier S, Chillik C. Higher levels of sperm apoptosis and lipid peroxidation are related to increasing male age in infertile patients. Fertil Steril. 2012;98:S82. DOI: 10.1016/j.fertnstert.2012.07.297

Alvarez Sedó C, Barros MA, Boudri HU, Rougier N, Papier $S$, Nodar $F$. Changes in DNA fragmentation during sperm preparation for ICSI over time. JBRA Assist Reprod. 2013;17:109-14. DOI: 10.5935/1518-0557.20130016

Avendaño C, Franchi A, Taylor S, Morshedi M, Bocca S, Oehninger S. Fragmentation of DNA in morphologically normal human spermatozoa. Fertil Steril. 2009a;91:107784.PMID: 18440529DOI: 10.1016/j.fertnstert.2008.01.015

Avendaño C, Franchi A, Duran H, Oehninger S. DNA fragmentation of normal spermatozoa negatively impacts embryo quality and intracytoplasmic sperm injection outcome. Fertil Steril. 2009b;94:549-57. PMID: 19339003 DOI: $10.1016 /$ j.fertnstert.2009.02.050

Barratt CL, Aitken RJ, Björndahl L, Carrell DT, de Boer $\mathrm{P}$, Kvist U, Lewis SE, Perreault SD, Perry MJ, Ramos L, Robaire B, Ward S, Zini A. Sperm DNA: organization, protection and vulnerability: from basic science to clinical applications-a position report. Hum Reprod. 2010;25:824-38. PMID: 20139429 DOI: 10.1093/humrep/dep465

Boe-Hansen GB, Fedder J, Ersbøll AK, Christensen P. The sperm chromatin structure assay as a diagnostic tool in the human fertility clinic. Hum Reprod. 2006;21:1576-82. PMID: 16543258 DOI: 10.1093/humrep/del019

Borini A, Tarozzi N, Bizzaro D, Bonu MA, Fava L, Flamigni C, Coticchio G. Sperm DNA fragmentation: paternal effect on early post-implantation embryo development in ART. Hum Reprod. 2006;21:2876-81. PMID: 16793992 DOI: 10.1093 /humrep/del251

Bungum M, Humaidan $\mathrm{P}$, Spano M, Jepson K, Bungum $L$, Giwercman A. The predictive value of sperm chromatin structure assay (SCSA) parameters for the outcome of intrauterine insemination, IVF and ICSI. Hum Reprod. 2004;19:1401-8. PMID: 15117894 DOI: $10.1093 /$ humrep/deh280

Bungum $M$, Humaidan $P$, Axmon A, Spano $M$, Bungum L, Erenpreiss J, Giwercman A. Sperm DNA integrity assessment in prediction of assisted reproduction technology outcome. Hum Reprod. 2007;22:174-9. PMID: 16921163 DOI: $10.1093 /$ humrep/del326
Carrell DT, Liu L, Peterson CM, Jones KP, Hatasaka HH, Erickson L, Campbell B. Sperm DNA fragmentation is increased in couples with unexplained recurrent pregnancy loss. Arch Androl. 2003;49:49-55. PMID: 12647778 DOI: $10.1080 / 01485010290099390$

Chohan KR, Griffin JT, Lafromboise M, De Jonge CJ, Carrell DT. Comparison of chromatin assays for DNA fragmentation evaluation in human sperm. J Androl. 2006;27:53-9. PMID: 16400078 DOI: $10.2164 /$ jandrol.05068

Cordelli E, Eleuteri P, Leter G, Rescia M, Spanò M. Flow cytometry applications in the evaluation of sperm quality: semen analysis, sperm function and DNA integrity. Contraception. 2005;72:273-9. PMID: 16181971 DOI: $10.1016 /$ j.contraception.2005.03.004

De Iuliis GN, Thomson LK, Mitchell LA, Finnie JM, Koppers AJ, Hedges A, Nixon B, Aitken RJ. DNA damage in human spermatozoa is highly correlated with the efficiency of chromatin remodeling and the formation of 8-hydroxy-2'-deoxyguanosine, a marker of oxidative stress. Biol Reprod. 2009;81:517-24. PMID: 19494251 DOI: $10.1095 /$ biolreprod.109.076836

Evenson DP, Darzynkiewicz Z, Melamed MR. Relation of mammalian sperm chromatin heterogeneity to fertility. Science. 1980;210:1131-3. PMID: 7444440 DOI: $10.1126 /$ science. 7444440

Evenson DP, Larson KL, Jost LK. Sperm chromatin structure assay: its clinical use for detecting sperm DNA fragmentation in male infertility and comparisons with other techniques. J Androl. 2002;23:25-43. PMID: 11780920 DOI: 10.1002/j.1939-4640.2002.tb02599.x

Fernández JL, Muriel L, Goyanes V, Segrelles E, Gosálvez J, Enciso M, LaFromboise M, De Jonge C. Simple determination of human sperm DNA fragmentation with an improved sperm chromatin dispersion test. Fertil Steril. 2005;84:833-42. PMID: 16213830 DOI: $10.1016 /$ j.fertnstert.2004.11.089

Góngora-Rodríguez A, Fontanilla-Ramírez D. The influence of sperm DNA fragmentation on assisted reproduction techniques and embryo quality. Rev Colomb Obstet Ginecol. 2010;61:160-4.

Gorczyca W, Traganos F, Jesionowska H, Darzynkiewicz $Z$. Presence of DNA strand breaks and increased sensitivity of DNA in situ to denaturation in abnormal human sperm cells: analogy to apoptosis of somatic cells. Exp Cell Res. 1993;207:202-5. PMID: 8391465 DOI: $10.1006 /$ excr.1993.1182

Greco E, Scarselli F, Iacobelli M, Rienzi L, Ubaldi F, Ferrero S, Franco G, Anniballo N, Mendoza C, Tesarik J. Efficient treatment of infertility due to sperm DNA damage by ICSI with testicular spermatozoa. Hum Reprod. 2005;20:22630. PMID: 15539441 DOI: 10.1093/humrep/deh590

Guerif F, Lemseffer M, Leger J, Bidault R, Cadoret V, Chavez C, Gasnier O, Saussereau MH, Royere D. Does early morphology provide additional selection power to blastocyst selection for transfer? Reprod Biomed Online. 2010;21:5109. PMID: 20817557 DOI: 10.1016/j.rbmo.2010.06.043

Lewis SE, Aitken RJ. DNA damage to spermatozoa has impacts on fertilization and pregnancy. Cell Tissue Res. 2005;322:3341. PMID: 15912407 DOI: 10.1007/s00441-005-1097-5 
Li YH, Wang C, Meng K, Chen LB, Zhou XJ. Influence of survivin and caspase-3 on cell apoptosis and prognosis in gastric carcinoma. World J Gastroenterol. 2004;10:19848. PMID: 15222052 DOI: 10.3748/wjg.v10.i13.1984

Makhlouf AA, Niederberger C. DNA integrity tests in clinical practice: it is not a simple matter of black and white (or red and green). J Androl. 2006;27:316-23. PMID: 16469966 DOI: $10.2164 /$ jandrol.05217

Meseguer M, Martínez-Conejero JA, O'Connor JE, Pellicer A, Remohí J, Garrido N. The significance of sperm DNA oxidation in embryo development and reproductive outcome in an oocyte donation program: a new model to study a male infertility prognostic factor. Fertil Steril. 2008;89:1191-9. PMID: 17681311 DOI: 10.1016/j.fertnstert.2007.05.005

Morris ID, Ilott S, Dixon L, Brison DR. The spectrum of DNA damage in human sperm assessed by single cell gel electrophoresis (Comet assay) and its relationship to fertilization and embryo development. Hum Reprod. 2002;17:990-8. PMID: 11925396 DOI: $10.1093 /$ humrep/17.4.990

Nasr-Esfahani MH, Salehi M, Razavi S, Anjomshoa M, Rozbahani S, Moulavi F, Mardani M. Effect of sperm DNA damage and sperm protamine deficiency on fertilization and embryo development post-ICSI. Reprod Biomed Online. 2005;11:198-205. PMID: 16168218 DOI: $10.1016 / \mathrm{S} 1472-6483(10) 60959-5$

Nel-Themaat L, Nagy ZP. A review of the promises and pitfalls of oocyte and embryo metabolomics. Placenta. 2011;32:S257-63. PMID: 21703683 DOI: $10.1016 /$ j.placenta.2011.05.011

Ni W, Xiao S, Qiu X, Jin J, Pan C, Li Y, Fei Q, Yang X, Zhang $L$, Huang $X$. Effect of sperm DNA fragmentation on clinical outcome of frozen-thawed embryo transfer and on blastocyst formation. PLoS One. 2014;9:e94956. PMID: 24733108 DOI: 10.1371/journal.pone.0094956

Rougier N, Uriondo H, Papier S, Checa MA, Sueldo C, Alvarez Sedó $\mathrm{C}$. Changes in DNA fragmentation during sperm preparation for intracytoplasmic sperm injection over time. Fertil Steril. 2013;100:69-7 PMID: 23561542 DOI: $10.1016 /$ j.fertnstert.2013.03.005
Sakkas D, Alvarez JG. Sperm DNA fragmentation: mechanisms of origin, impact on reproductive outcome, and analysis. Fertil Steril. 2010;93:1027-36. PMID: 20080235 DOI: 10.1016/j.fertnstert.2009.10.046

Seli E, Gardner DK, Schoolcraft WB, Moffatt O, Sakkas D. Extent of nuclear DNA damage in ejaculated spermatozoa impacts on blastocyst development after in vitro fertilization. Fertil Steril. 2004;82:378-83. PMID: 15302287 DOI: $10.1016 /$ j.fertnstert.2003.12.039

Sergerie M, Laforest G, Bujan L, Bissonnette F, Bleau G. Sperm DNA fragmentation: threshold value in male fertility. Hum Reprod. 2005;20:3446-51. PMID: 16085665 DOI: $10.1093 /$ humrep/dei231

Tavukçuoğlu IŞ, Al-Azawi T, Khaki AA, Khaki A, Khalil A, Al-Hasani S. Clinical value of DNA fragmentation evaluation tests under ART treatments. J Turk Ger Gynecol Assoc. 2012;13:270-4. PMID: 24592055 DOI: $10.5152 /$ jtgga.2012.44

Uriondo H, Alvarez Sedó C, Gil M.V, Frazer P, Serna J, Nodar F. Severe teratozoospermia and male age increase levels of sperm apoptosis in infertile patients. Fertil Steril. 2011;96:S72. DOI: 10.1016/j.fertnstert.2011.07.275

Virro MR, Larson-Cook KL, Evenson DP. Sperm chromatin structure assay (SCSA) parameters are related to fertilization, blastocyst development, and ongoing pregnancy in in vitro fertilization and intracytoplasmic sperm injection cycles. Fertil Steril. 2004;81:1289-95. PMID: 15136092 DOI: $10.1016 /$ j.fertnstert.2003.09.063

WHO - World Health organization. WHO laboratory manual for the examination and processing of human semen. 5th ed. Geneva: WHO Press; 2010.

Zini A, Sigman M. Are tests of sperm DNA damage clinically useful? Pros and cons. J Androl. 2009;30:219-29. PMID: 19059901 DOI: $10.2164 /$ jandrol.108.006908 